\title{
Reshaping Risk Disclosure through Integrated Reporting: Evidence from Italian Early Adopters
}

\author{
Francesca Manes-Rossi ${ }^{1}$, Giuseppe Nicolò ${ }^{1}$ \& Rebecca Levy Orelli ${ }^{2}$ \\ ${ }^{1}$ DISA-MIS, Universityof Salerno, Salerno, Italy \\ ${ }^{2}$ Department of Management, University of Bologna, Bologna, Italy \\ Correspondence: Francesca Manes Rossi, Department of Management and Innovation Systems, University of \\ Salerno, Via Giovalnni Paolo II, 132, 84084, Fisciano (SA), Italy. Tel: 0039-089-963-131. E-mail: \\ fmanesrossi@unisa.it
}

Received: June 21, 2017

doi:10.5539/ijbm.v12n10p11
Accepted: August 30, $2017 \quad$ Online Published: September 9, 2017

URL: https://doi.org/10.5539/ijbm.v12n10p11

\begin{abstract}
The purpose of this paper is to explore Integrated Reporting (IR) and risk disclosure (RD) and demonstrating the interconnection between business strategies and risk. Through a content analysis, the paper explores the management commentary and Integrated reporting of Italian companies at the end of 2015.

The study reveals that many of the companies have embedded financial reporting into IR. We find extensive information about risks and opportunities, in relation to the management of the six capitals. The paper represents an investigation into risk disclosure in IR. It adds knowledge to the opportunity offered by IR in meeting stakeholder's information needs, compared to traditional tools of corporate reporting.

The results could be of interest both for legislator and standards setters, to bring them up to date with enhanced disclosure of risk and opportunities which IR offers with respect to the more traditional forms of disclosure.

This is the first country-based study investigating risk disclosure provided through IR looking at three different dimensions: the metrics of RD (monetary or non-monetary); the outlook orientation (past, present or future) and the type of risk news (good or bad news). The results are relevant to detect how companies act and what can be done to improve risk disclosure.
\end{abstract}

Keywords: integrated reporting, risk disclosure, management commentary, Italian firms

\section{Introduction}

The uncertainty of the economic environment, coupled with the persisting effects of the global financial crisis, have intensified the interest towards risk management and risk disclosure (RD hereafter) by companies in searching of policies to minimise risks. As scholars have noted (J. Solomon, A. Solomon, \& Norton, 2000), the process of management risk cannot be confined into a department devoted to controlling accounting data. It demands a more comprehensive approach that takes into account the organisation's specific business model. Investors demand information about risk management systems as well as future risks and uncertainties.

The risk reporting is an essential part of financial management and investment practice since investors use information on risk for making decisions on their investment (Abraham \& Cox, 2007). RD is seldom compulsory and may be positioned in the grey area between mandatory and voluntary disclosure (Lajili \& Zéghal, 2005). Regulation on non-financial RD is limited in the international arena as most of the standards and laws are related to corporate disclosure.

In December 2010, the IASB International Accounting Standards Board issued the IFRS practice statement on 'Management Commentary', a narrative report - embedded in the annual report - aimed at providing information about objectives and the related strategies as well as about risk and uncertainties faced by the firms. However, this is a non-binding document (Enslin, Bruwer \& Viljoen, 2015) and there is no accounting standard for the MC, but some guidelines on MA are issued. Nonetheless, traditional financial reporting is more likely to disclose the financial situation of a company in a retrospective manner (Eccles \& Serafeim, 2014). Other tools, such as sustainability reporting, have enlarged the corporate disclosure border, and are perceived by investors, analysts and other stakeholders as a means not able to capture and disclose the relationship between business strategy and risk (Eurosif \& ACCA, 2013). 
Since the creation of the International Integrated Reporting Council (IIRC) and, moreover, the publication of the $<$ IR $>$ Framework, both scholars (Busco, Frigo, Quattrone \& Riccaboni, 2013; Moolman, Oberholzer \& Steyn, 2016; Kim, Mass \& Perego, 2017) and consultants have emphasised the challenges of the IR disclosing strategies related to risks faced by companies. As recently highlighted by scholars, IR strengthens financial analysts' earnings forecasts (Kim et al., 2017) offering a clearer overview of future trends and perspectives and, more in general, redefining the borders of corporate accountability (Busco et al., 2013).

The $<\mathrm{IR}>$ Framework clarifies that "Integrated thinking takes into account the connectivity and interdependencies between the range of factors that affect an organization's ability to create value over time, including among others [...] how the organization tailors its business model and strategy to respond to its external environment and the risks and opportunities it faces"(IIRC, 2013, p.2). Previous research has shown that in South Africa, the sole country where IR is mandatory for listed companies, "integrated reporting has driven change towards integrated thinking between strategy, risks and opportunities" (Moolman et al., 2016, p.600). Some initial analysis on South African companies have also pinpointed the "possibility of reporting on the governance of risk being a compliance-based exercise rather than an example of effective stakeholder communication" (Raemaekers, Maroun, \& Padia, 2016, p. 41).

Additionally that issue has not yet been investigated in contexts with limited tradition in RD and where IR is prepared on a voluntary basis.

Grounding on the vast literature on RD (among others Solomon et al., 2000; Lajili \& Zéghal, 2005; Linsley \& Shrives, 2006; Linsley \& Lawrence, 2007; Abraham \& Shrives, 2014), and on the growing strand of literature on IR and risk disclosure (Quarchioni \& Trovarelli 2013; Moolman et al., 2016; Raemaekers et al., 2016), the paper aims to define the role of IR in enhancing risk disclosure and demonstrating the interconnection between business strategies and risk.

More precisely, by analysing the IR published by Italian companies paired with the management commentary, when not embedded in the IR, the present research intends to provide a picture of determinants and features of the $\mathrm{RD}$ as provided in the above cited documents.

Starting from the analysis of the type of risk as defined by previous studies, the present research investigates further, the metrics adopted for RD (monetary or non-monetary), the outlook orientation (past, present or future), and the type of risk news (good or bad news), through a content analysis. The final aim is to assess the level of risk disclosure embedded in IR and make a comparison with the RD provided in the management commentary. Data collected related to the financial year 2015 on of 18 Italian firms, which draws on their IR following the IIRC framework.

The results show that the majority of the companies publish a single report (named IR or annual report) which includes both the content of IR indicated by the IIRC framework and the traditional financial statement accounting documents. Secondly, the IR is a suitable tool to communicate risk disclosure to stakeholders, since, on average each sampled firm discuss an appropriate amount of RD information. Thirdly, the risk category mostly disclosed is Operations risks, followed by Financial risks and Integrity risks, while the lesser discussed is Empowerment risks; moreover, the majority of RD information discussed are non-monetary, past related and neutral news.

The paper is organised as follows. The next section provides a background on risk disclosure and integrated reporting. Section 3 presents the methodology and set the context for the empirical analysis. Results are presented and discussed in section 4, whilst the last section draws some conclusions emerging from the key finding and paves the way for further research on risk disclosure through IR.

\section{Risk disclosure and Integrated Reporting: Theoretical Background}

The high uncertainty which affects organisations nowadays has led to a broad movement of "risk management of everything" (Power 2004) which, in turn, has nourished the development of international framework aimed at prescribing how organisations should face risks. Consequently, while risk management has been considered as a mechanism to enhance accountability (Spira \& Page, 2003), it has also been consolidated in the idea that risk and performance are two sides of the same coin (Van der Stede, 2009).

Thus, a growing attention has been paid to how organizations disclose their risks both by scholars (Solomon et al., 2000; Lajili \& Zéghal, 2005; Linsley \& Shrives, 2006; Linsley \& Lawrence, 2007; Abraham \& Shrives, 2014; Halbouni \& Yasin, 2016), and standard setters (American Institute of Certified Public Accountants [AICPA], 1994; German Accounting Standards [GASB], 2001; Institute of Chartered Accountants in England and Wales [ICAEW], 2002 and 2011; International Organization for Standardization [ISO], 2009; International Accounting 
Standard boards [IASB], 2010) addressed also to improve enterprise risk management systems (Committee of Sponsoring Organizations of the Treadway Commission [COSO], 2004 at the moment under revision).

Previous studies have discussed characteristics of RD and the regulatory power (Woods \& Reber's, 2003, Beretta \& Bozzolan, 2004; Lajili \& Zeghal, 2005) possible determinants (Beretta \& Bozzolan, 2004; Linsley \& Shrives, 2006; Abraham \& Cox, 2007; Oliveira, Lima Rodrigues \& Craig, 2011; Allini, Manes Rossi \& Macchioni, 2014; Allini, Manes Rossi \& Hussainey, 2016; Halbouni \& Yasin, 2016) as well as effects of RD (Linsley, Shrives \& Crumpton, 2006; Dobler, 2008).

Being that our research related to the characteristics of $\mathrm{RD}$, previous results collected by scholars deserves to be presented. Solomon et al. (2000) highlights the importance of firm-specific RD, instead of generic risk. While the first can change year after year, the latter is more likely to be constant over time, thus is not relevant for stakeholders.

Woods and Reber (2003) compare RD by German and UK companies, revealing that regulation has a positive effect on risk reporting. Lajili and Zeghal (2005), analysing the financial reporting of listed Canadian companies through a content analysis, found that $\mathrm{RD}$ disclosure is embedded both in the Management and Discussion Analysis (MDA), as well as in the notes, financial risk being the most frequently disclosed risk. Moreover, their research also highlights that $\mathrm{RD}$ is almost always qualitative in nature and rather vague. Beretta and Bozzolan (2004) analysing RD in the MDA of 85 Italian listed companies, reveals a limited impact in quantitative terms, especially in regard to the potential effect that derives from future risks. The research also pinpoints that Italian companies are more inclined to disclose past rather than future risk. Linsley and Shrives (2006) reveal that RD is mainly qualitative in nature, being companies reluctant to quantify the risks they are facing. Along the same vein, Oliveira et al. (2011) found that Portuguese companies tend to have a vague RD, mostly qualitative in nature and backward-looking, considering that this kind of RD is inadequate to satisfy stakeholder' s informational needs.

More recently, Abraham and Shrives (2014) confirms once more how RD in the annual report is often a 'boilerplate', being difficult for readers to link risk items together.

Previous studies suggest that the quality of risk disclosure should be analysed considering several dimensions, at the very least the metrics adopted to quantify risks (monetary or non-monetary) the outlook orientation (past, present or future) and the type of risk news (good or bad news).

While examining RD, many prior studies have adopted content analysis, in some cases using sentences as the recording unit (Beretta \& Bozzolan, 2004; Linsley \& Shrives, 2006; Amran, Manaf Rosli Bin \& Che Haat Mohd Hassan, 2009; Oliveira et al. 2011), or words (Abraham \& Cox, 2007). The first approach has been adopted in this research, as better clarified in the next section.

Correspondingly, the theoretical lens borrowed to discuss motivations and determinants of RD varies among authors.

Stakeholders theory has been widely used to examine corporate social and environmental disclosure, also in regard to intellectual capital components (Guthrie, Petty \& Ricceri, 2006). Recent studies grounded on this theory for discussing the disclosure of climate changes related risks (Gray, Owen \& Adams, 1996; Amran et al. 2009; J. F. Solomon, A. Solomon, Norton, \& Joseph, 2011) as well as IR practices (García-Sánchez, Rodríguez-Ariza, \& Frías-Aceituno, 2013; Haller \& van Staden, 2014).

The ethical branch of the stakeholders theory sets that all stakeholders have an equal right to be informed, despite the fact they are entitled to have or not to have a direct role in the survival of the organisation (Degan, 2000). Following this approach, managers should operate to create advantages for all of them. On the contrary, the positive branch of the stakeholders theory (Watts \& Zimmerman, 1986) argues that the management is more prone to satisfy the informational needs of primary and powerful stakeholders. Various interested parties may be concerned about risks and related consequences that the organisation must face at present as well as in the future. The stakeholders theory can be tested to determine the extent to which organisations are responding to stakeholders' expectations related to risks and opportunities.

With the aim of enhancing the level of information provided to different stakeholders, the last decades have witnessed a growing attention at various tools related to corporate reporting, attuned to satisfy an increasing need for non-financial information, especially those related to the environment, risk and governance. (Solomon et al., 2011).

Despite the increasing production of disclosure of non-financial information, stakeholders seem to be still unsatisfied with information related to risk. Results collected by a recent survey considering investors, analysts and other stakeholders (Eurosif \& ACCA, 2013), show that 73 percent of them disagree that sustainability 
reporting links to business strategy and risk. These results show an emergence for the need of further research by scholars and efforts by standard setters to fill the gap.

Standards setter and consulting companies (IASB, 2010; IIRC, 2013; Pricewaterhousecoopers [PwC], 2013; Ernst and Young [EY], 2014; Deloitte, 2016) agree on the requirement for a holistic reporting on the main risks and opportunities. For this reason, IIRC requires companies adopting IR to disclose "any real risks (whether they be in the short, medium or long term) that are fundamental to the ongoing ability of the organisation to create value and that could have extreme consequences" (IIRC Framework, par. 4. 26 p.27).

Scholars have started to discuss the usefulness and the role of IR recently, albeit a growing literature on the matter is developing quickly. The first stage of studies on IR has witness a fundamental attention to factors explaining the development of IR practices (Elkington, 2009; Eccles \& Krzus, 2010; Krzus, 2011), as well as the structure of the document (Abeysekera 2013) with special regard to IR Frameworks (Perego, Kennedy, \& Whiteman, 2016). A more recent strand of literature is about determinants and effects of IR (García-Sánchez et al., 2013; Frías-Aceituno, Rodriguez-Ariza, \& Garcia-Sanchez, 2015). Some of that studies discuss the effect of disclosure through IR on investors and financial markets (Barth, Cahan, Chen, \& Venter, 2016), also showing special attention to RD (Quarchioni \& Trovarelli 2013; Enslin et al., 2015; Moolman et al., 2016; Raemaekers et al., 2016).

Our study intends to contribute to this strand of research, by analysing characteristics of RD. As highlighted by de Villiers, Rinaldi and Unerman (2014), risk and opportunities belong to one of the critical areas of disclosure in IR practices. Thus, further research on the behaviour of companies would be beneficial for a better understanding and for providing a base for reflection for standard setters and regulators.

In particular, the research is timely considering that trend toward integrated reporting encompasses both financial and nonfinancial disclosures, with a growing attention on RD to increase in the future (Adams \& Simnett 2011; Cohen, Krishnamoorthy \& Wright 2017).

More precisely, in the present research the concept of risk disclosure adopted is the one proposed and operationalised by Linsley and Shrives (2006, p. 389). Consistently, we consider "risk disclosures if the reader is informed of any opportunity or prospect, or of any hazard, danger, harm, threat or exposure, that has already impacted upon the company or may impact upon the company in the future or of the management of any such opportunity, prospect, hazard, harm, threat or exposure". Consequently, our research detects both information related to both the bad and good news, and, as in Linsley and Shrives (2006), risk disclosure has been classified under six categories (financial risks, operations risks, empowerment risks, information processing and technology risks, integrity risks and strategic risks).

\section{Research Context and Design}

To understand the role of the management commentary, as well as the integrated reporting disclosure, in the Italy, it is important to shed light on both the legal system and the ownership structure of the firms. The Italian legal system falls into the code law countries or Napoleonic countries (Jaggi \& Low, 2000; Peters, 2000), a tax-dominated cluster of continental European countries (Nobes, 2011). There is a predominance of small and medium-sized firms, for the most part family firms, and few medium and large size companies (Beckt 1997, Melis, Carta \& Gaia, 2012).

Looking at the ownership structure, the $86 \%$ of the Italian companies are family businesses with a small or medium size (99\%) and with about 250 companies listed on the Italian Stock Exchange (research of the Italian Chamber of Commerce in 2013). The ownership structure condensed in a few hands, and for the most part of the same families, determines a limited role of the stock market against the powerful role of banks in credit and financing (Alexander \& Servalli, 2011; Jaggi, Allini, Manes Rossi \& Caldarelli, 2016).

Listed companies have an increased demand for disclosure, as they must show policies that meet the information needs of investors to reduce information asymmetry between managers and investors, and also more generally, stakeholders. In particular, in regard to the risk disclosure accounting setting, the Italian listed firms draft the financial statements following the international set of accounting standards (IAS/IFRS). Currently, there is still no specific international accounting standard requiring companies to prepare the management commentary. However, in 2010, the IASB drew up a practice statement which encourages companies to draft a management commentary (Haller \& Van Staden, 2014; Enslin et al., 2015).

One of the main elements of the management commentary is represented by the description of "entity's principal risk exposures and changes in those risks, together with its plans and strategies for bearing or mitigating those risks, as well as disclosure of the effectiveness of its risk management strategies" with a focus on operational, strategic, commercial and financial risk. (IASB 2010, p.13). 
To increase transparency in disclosure and reduce information asymmetry, the European Union imposed the Directive 2014/95/UE on disclosure of non-financial and diversity. The Directive specifies how companies might disclose social and environmental information in their annual reports. The provision applies to companies with over 500 employees within the public interest domain, such as listed companies, banks, insurance companies, which are of significant public relevance because of the nature of their business, size or corporate status. The Directive provisions are particularly important as they are required to include policies, main risks and outcomes related to environmental information. Nevertheless, as stated above, the Italian context is influenced by the Italian Civil Code and the national set of accounting standards (OIC) especially for unlisted firms. Art. 2428 of the Civil Code requires firms to provide a management commentary with the description of the principal risks and uncertainties to which the company is exposed, as well as the disclosure of management and coverage policy linked to financial instruments held with a focus on liquidity, credit and price risks exposure.

Thus, in order to answer the research question about the state of the art of the risk disclosure provided in IR and where possible in the management commentary, all the Italian companies in the year 2015 disclosed an integrated reporting, both as a separate document rather than as an integrated document with a financial statement, have been considered.

The reports were analysed throughout a content analysis focused on the meaning of the sentences disclosed (Smith \& Taffler, 2000). According to previous RD studies (Lajili \& Zèghal, 2005; Linsley \& Shrives, 2006; Amran et al., 2009; Oliveira et al., 2011) sentences have been used as a unit of analysis. Milne and Adler (1999, p.243) stated about the use of sentences: "As a basis for coding sentences are far more reliable than any other unit of analysis [....] Individual words have no meaning to provide a sound basis for coding social and environmental disclosures without a sentence or sentences for context".

The content analysis, as a technique of investigation, can push researchers beyond the text written within the analysed documents, and, in turn, to show the reliability of inferences on the messages of interest (Weber, 1990). The sample under investigation is made up of all the Italian firms, which prepared an Integrated reporting following the IIRC guidelines for 2015, the most recent available year of disclosure. The Italian context was selected because of the characteristics of previous sustainability practices that have played a significant role in Italy over time (e.g., Adams \& Kuasirikun, 2000; Kolk, 2005). Companies committed to IR were identified using the dataset Thomson Reuters ASSET4, which focuses on systematic CSR information. To confirm completeness of the selection of companies producing an IR, the potential candidates were also searched using the research tool available in the IR database, and from referrals made by integrated reporters. From this process, it was possible to identify 19 companies. However, one of them failed to upload its Integrated report on its website so that 18 firms providing their IR documents are the basis of the present study. Also, to analyse risk disclosure, for each company the management commentary was searched and, if available, downloaded.

The content analysis of the risk disclosures was manually performed on Integrated reporting and management commentary, both when included in the IR rather than when included in the traditional financial statements. To assure reliability to the content analysis with reference to the coding phase, a team of two people were involved in the activity after having performed a test of inter-rater reliability used to check for consistency in coding (Milne \& Adler, 1999). The coding tool replicates those adopted by Linsley and Shrives (2006), subsequently reproduced by Amran et al. (2009). The risks are divided into financial and non-financial (operations risks, empowerment risks, information processing and technology risks, integrity risks and strategic risks). Moreover, following the approach of several RD scholars (Beretta \& Bozzolan, 2004; Linsley \& Shrives, 2006; Oliveira et al., 2011) also the risk disclosure sentence characteristics (or semantic characteristics) were analysed by exploring three dimensions related to: the metrics of risk (monetary or non-monetary); the outlook orientation (past, present and future) and the type of news (good, bad or neutral news).

Each risk disclosure sentence was recorded on a coding sheet and classified for the type of risk (financial, operations, empowerment, information processing and technology, integrity and strategic); the metrics of RD (monetary or no monetary); the outlook orientation (past, present or future) and the type of news (good or bad). By coding for meaning rather than looking for simple words, only sentences with clear and precise reference to risk have been accepted, thus avoiding broad and misleading concepts. The sentences with a generic and vague reference to risk were excluded.

\section{Results and Discussion}

As argued by Guthrie et al. (2006), a content analysis conducted on the annual report can be a useful research technique to test, in the light of stakeholder theory, if the Italian companies are meeting the stakeholders expectations.

As stated above, stakeholder theory stresses the importance of stakeholders as strategic company resource 
providers. Thus it is necessary to satisfy their information needs related both to the firm's economic performances and the firm's environmental, social and governance issues (Guthrie et al., 2006; Haller \& Van Staden, 2014). In particular in recent years, the focus of the stakeholders has sharply shifted towards risk and risk management disclosure (Oliveira et al., 2011; Abraham \& Shrives, 2014). One of the aims in preparing the IR is to improve the accountability towards stakeholders by providing an integrated and connecting description of strategic, performance, governance, environmental and risk and opportunities issues (Moolman et al., 2016).

As a consequence, the content analysis conducted on IR can offer interesting insights.

The results of content analysis conducted on the IR of the 18 firms are shown in table 1 . These results, as already noted by Moolman et al. (2016) and Raemaekers et al. (2016) show that Integrated Reporting is a suitable tool in disseminating RD information to stakeholders, indeed, a total of $2731 \mathrm{RD}$ sentences has been found. On average, each selected firm reports $151.72 \mathrm{RD}$ sentences, a greater result than those obtained by several previous scholars (Lajili \& Zéghal, 2005; Linsley \& Shrives, 2006; Amran et al., 2009; Oliveira et al., 2011) in their similar studies on $\mathrm{RD}$ in the annual report conducted throughout different countries.

Table 1. Content analysis results for type of risk and RD sentence characteristics

\begin{tabular}{|c|c|c|c|c|c|c|c|}
\hline Categories & $\begin{array}{r}\text { Total } \\
\text { disclosures } \\
\end{array}$ & Min & Max & Mean & $\begin{array}{r}\text { Media } \\
\mathrm{n}\end{array}$ & $\begin{array}{r}\text { Std. } \\
\text { Deviation } \\
\end{array}$ & Percentage \\
\hline Total number of risk disclosures & 2731 & 15 & 368 & $\begin{array}{r}151.7 \\
2\end{array}$ & 158.50 & 96.898 & $100.00 \%$ \\
\hline Number of financial risk disclosures & 454 & 0 & 168 & 25.22 & 11.50 & 41.075 & $16.62 \%$ \\
\hline $\begin{array}{l}\text { Number of non-financial risk } \\
\text { disclosures }\end{array}$ & 2277 & 13 & 315 & $\begin{array}{r}126.5 \\
0\end{array}$ & 136.50 & 84.942 & $83.38 \%$ \\
\hline $\begin{array}{l}\text { Number of operations risk } \\
\text { disclosures }\end{array}$ & 1600 & 10 & 228 & 88.89 & 89.00 & 64.336 & $58.59 \%$ \\
\hline $\begin{array}{l}\text { Number of empowerment risk } \\
\text { disclosures }\end{array}$ & 22 & 0 & 12 & 1.22 & 0.00 & 3.098 & $0.81 \%$ \\
\hline $\begin{array}{l}\text { Number of inf.processing and } \\
\text { technology risk disclosures }\end{array}$ & 156 & 0 & 27 & 8.67 & 5.50 & 8.984 & $5.71 \%$ \\
\hline Number of integrity risk disclosures & 340 & 0 & 74 & 18.89 & 12.50 & 19.381 & $12.45 \%$ \\
\hline Number of strategic risk disclosures & $\begin{array}{r}159 \\
2277\end{array}$ & 0 & 39 & 8.83 & 4.50 & 9.823 & $5.82 \%$ \\
\hline Number of monetary risk disclosures & 169 & 0 & 64 & 9.39 & 2.00 & 16.839 & $6.19 \%$ \\
\hline $\begin{array}{l}\text { Number of non-monetary risk } \\
\text { disclosures }\end{array}$ & 2562 & 15 & 358 & $\begin{array}{r}142.3 \\
3\end{array}$ & 149.50 & 92.548 & $93.81 \%$ \\
\hline & 2731 & & & & & & $100.00 \%$ \\
\hline $\begin{array}{l}\text { Number of past risk disclosures } \\
\text { Number of future risk disclosures }\end{array}$ & $\begin{array}{r}1367 \\
201\end{array}$ & $\begin{array}{l}4 \\
0\end{array}$ & $\begin{array}{r}188 \\
41\end{array}$ & $\begin{array}{l}75.94 \\
11.17\end{array}$ & $\begin{array}{r}72.00 \\
8.50\end{array}$ & $\begin{array}{l}50.327 \\
12.065\end{array}$ & $\begin{array}{r}50.05 \% \\
7.36 \%\end{array}$ \\
\hline $\begin{array}{l}\text { Number of present/ non-time } \\
\text { specific risk disclosures }\end{array}$ & 1163 & 6 & 160 & 64.61 & 68.50 & 47.133 & $42.59 \%$ \\
\hline & 2731 & & & & & & $100.00 \%$ \\
\hline Number of good news disclosures & 559 & 2 & 94 & 31.06 & 29.00 & 22.877 & $20.47 \%$ \\
\hline Number of bad news disclosures & 223 & 0 & 56 & 12.39 & 7.50 & 14.987 & $8.17 \%$ \\
\hline Number of neutral news disclosures & 1949 & 12 & 234 & $\begin{array}{r}108.2 \\
8\end{array}$ & 118.50 & 68.777 & $71.37 \%$ \\
\hline $\begin{array}{l}\text { Number of risk categories disclosed } \\
\text { Number of specific RD section in IR }\end{array}$ & 2731 & 2 & $\begin{array}{l}6 \\
3\end{array}$ & $\begin{array}{l}4.77 \\
1.11\end{array}$ & $\begin{array}{l}5 \\
1\end{array}$ & $\begin{array}{l}1.060 \\
0.758\end{array}$ & $100.00 \%$ \\
\hline
\end{tabular}

The result is consistent with Stakeholder Theory where voluntary disclosure is seen as a useful tool to satisfy the call of stakeholders for more transparency and accountability on a firm's activities and their impact on value creation (Guthrie et al., 2006). Among these, the large amount of risk disclosures found (table 1), can help investors in assessing the company's risk profile, reducing uncertainty and enhancing resources allocation, leading to reduce the cost of the firm's capital (Deumes \& Knechel, 2008; Haller \& Van Staden, 2014; Halbouni 
\& Yasin, 2016; Moolman et al. 2016).

As shown in table 1, each company, on average, discloses about four types of risk with a minimum of two types of RD and a maximum of six. The type of risk most disclosed is operations risk with a total of 1600 sentences (58.59\% on the total). This result is justified by the attention paid in IR to environmental, health and safety and customer satisfaction issues in line with both the GRI guidelines than the IR framework principles. Most of the companies have adopted an integrated approach by drafting a single document including both the contents indicated by the IIRC framework and those required by regulation on the annual report. Only five firms prepare two separated reports. The majority of companies, also follow the Global reporting Index (GRI) in drafting the IR. In this way, they can pay close attention to the environmental and job security issues and related risks especially in sections devoted to Human and Natural Capitals. Results are consistent with Linsley and Shrives (2006); Amran et al. (2009) and Vandemaele et al. (2009) who found an high number of operations risk disclosures in their studies, conducted respectively, on a sample of UK; Malaysian; UK and Belgian companies.

The other risk categories mostly disclosed are financial risk with a total of 454 sentences ( $16.62 \%$ of the total) and integrity risk with a total of 340 sentences $(12.45 \%$ of the total). These results are linked, on the one hand, to the presence of four banking companies which are heavily focused on the monitoring and management of interest rate, liquidity and credit risks with a specific disclosure section. On the other hand, a large amount of attention has been devoted to the discussion concerning management and prevention of risks related to corruption, fraud and illegal acts with specific sections as required by GRI G4 guidelines. Finally, the less discussed type of risk is empowerment risk with only 22 total sentences $(0.81 \%)$. The latter result is the consequence of a limited attention of considered firms in disclosing risks related to outsourcing, change readiness and performance incentives.

In regard to the $\mathrm{RD}$ sentences characteristics, the majority of firms $(93.81 \%)$ disclose non-monetary risk information and only a small percentage of them $(6.19 \%)$ quantify their risk information. This result is consistent with previous studies by Beretta and Bozzolan (2004), Linsley and Shrives (2006) and Oliveira et al. (2011) and highlights the difficulties for managers in measuring the risk and its impacts on firms in monetary terms. Results also reveal the unwillingness to communicate detailed information on risks to their competitors (Lajili \& Zéghal, 2005; Linsley \& Shrives, 2006; Abraham \& Shrives, 2014).

Moreover, consistent with the results of Beretta and Bozzolan (2004) and Oliveira et al. (2011) and not consistent with those of Linsley and Shrives (2006), most of the risk related information is focused on the past and present (92.64\%), with only a small percentage of RD information focused on the future (7.36\%). In the IR it is easier to find information on decisions already taken or ongoing risk management programs with related impacts rather than future decisions or programs with their expected impacts.

This result is in line with stakeholder theory and the backward-looking orientation of traditional financial statements and highlights an improvement in transparency and accountability towards the stakeholders community whose demand for non-mandatory information focused on risk grew rapidly after the economic crisis (Abraham \& Shrives, 2014; Enslin et al., 2015).

On the contrary, the limited disclosure of forward-looking information on risks represents a loss in terms of relevance of information to investors interested in assessing the future impact of the risks on the firm's economic performance, thus improving their decision making process (Beretta \& Bozzolan, 2004; Abraham \& Cox, 2007; Dobler, 2008; Enslin et al., 2015). A reduced forward-looking risk disclosure also represents an incomplete compliance of IR with IIRC framework requirements where companies are also required to report information on future risk prospects, even under uncertainty (IR framework, 2013, p.27).

Furthermore, consistent with the results obtained by Linsley and Shrives (2006), the majority of the RD disclosures are neutral (71.37\%), followed by good news (20.47\%) and bad news $(8.17 \%)$. This result could be explained by the desire for firms managers to conceal negative information in order to avoid legal costs or loss of reputation (Linsley \& Shrives, 2006) by providing only good or bad information which does not adversely affect the future cash flows and does not encourage competitors (Abraham \& Shrives, 2014).

Finally, observing the last row of table 1, it can be noted that each sampled firm presents, on average, one specific section devoted to Risk Disclosure with a minimum of zero and a maximum of three.

In summary, by comparing this last result with the previous just discussed, it can be noted that, in the Italian setting, risk disclosure can be found across integrated reporting rather than in a single section. More specifically, the possible impact of risks is presented in sections devoted to different capitals. So, it seems that the majority of firms, besides drafting a single section dealing with the risk and opportunities, have followed the principle of the 
connectivity of information (IR framework, 2013; Moolman et al., 2016). In fact, different RD information is presented within sections devoted to capitals, revealing the development of an "integrated thinking" (IR framework, 2013, p.2).

Table 2 shows the results of the comparative analysis conducted on the five companies which have drafted the integrated reporting as a separate document with respect to the financial statements in order to compare the Risk disclosure provided in the IR with the Risk disclosure provided in the MC embedded in the financial statement. The analysis was conducted, where possible, in order to strengthen the previous analysis performed only on the IR by demonstrating the potential of this document in communicating risk disclosure even with respect to other documents.

Despite the small size of companies analysed, results show the prevalence of RD information provided in Integrated reporting ( 684 sentences with a mean of $136.8 \mathrm{RD}$ sentences disclosed by each firm) compared to those provided in Management Commentary (310 sentences with a mean of $62 \mathrm{RD}$ sentences disclosed by each firm) by confirming the potential of the Integrated Reporting as a vehicle for communication of risk disclosure (Moolman et al., 2016; Raemaekers et al. 2016).

Generally, four categories of risks are more disclosed in IR than in MC: operations risk, empowerment risk, information processing and technology risk and integrity risk. On the contrary, financial risk and strategic risk are more disclosed in MC than in IR.

This result could be explained by two different prevailing document orientations. The Management Commentary as requested by IAS/IFRS (Practice Statement Management Commentary published by the IASB In 2010, p.13) is more geared to providing information about the risks associated with the implementation of strategies and the competitive environment, with a particular focus on strategic, financial, commercial and operational risks. Moreover, the Italian Civil Code (Art. 2428) places special emphasis on the management and coverage of financial, credit and liquidity risk. On the other hand, the IR Framework (2013, p. 27) requires the providing of information about the organization's main specific risks, including those related to continuous availability, quality and capital accessibility and the effects of the organization on the latter in the short, medium and long term, without a particular focus on a specific type of risk.

Table 2. Comparison between Risk disclosure in IR and Risk disclosure in MC

\begin{tabular}{|c|c|c|c|c|c|c|}
\hline \multirow[b]{2}{*}{ Categories } & \multicolumn{2}{|c|}{ Integrated reporting } & \multicolumn{4}{|c|}{ Management commentary } \\
\hline & Total disclosures & Mean & Percentage & Total disclosures & Mean & Percentage \\
\hline Total number of risk disclosures & 684 & 136.8 & $100.00 \%$ & 310 & 62 & $100.00 \%$ \\
\hline Number of financial risk disclosures & 20 & 4 & $2.92 \%$ & 70 & 14 & $22.58 \%$ \\
\hline Number of non-financial risk disclosures & 664 & 132.8 & $97.08 \%$ & 240 & 48 & $77.42 \%$ \\
\hline Number of operations risk disclosures & 499 & 99.8 & $72.95 \%$ & 153 & 30.6 & $49.35 \%$ \\
\hline Number of empowerment risk disclosures & 1 & 0.2 & $0.15 \%$ & 0 & 0 & $0.0 \%$ \\
\hline Number of inf. processing and technology risk disclosures & 44 & 8.8 & $6.43 \%$ & 6 & 1.2 & $1.94 \%$ \\
\hline Number of integrity risk disclosures & 86 & 17.2 & $12.57 \%$ & 18 & 3.6 & $5.81 \%$ \\
\hline Number of strategic risk disclosures & 34 & 6.8 & $4.97 \%$ & 63 & 12.6 & $20.32 \%$ \\
\hline Number of monetary risk disclosures & 12 & 2.4 & $1.75 \%$ & 11 & 2.2 & $3.55 \%$ \\
\hline \multirow[t]{2}{*}{ Number of non-monetary risk disclosures } & 672 & 134.4 & $98.25 \%$ & 299 & 59.8 & $96.45 \%$ \\
\hline & 684 & & $100.00 \%$ & 310 & & $100.00 \%$ \\
\hline Number of past risk disclosures & 402 & 80.4 & $58.77 \%$ & 173 & 34.6 & $55.81 \%$ \\
\hline Number of future risk disclosures & 42 & 8.4 & $6.14 \%$ & 18 & 3.6 & $5.81 \%$ \\
\hline \multirow[t]{2}{*}{ Number of non-time specific risk disclosures } & 240 & 48 & $35.09 \%$ & 119 & 23.8 & $38.39 \%$ \\
\hline & 684 & & $100.00 \%$ & 310 & & $100,00 \%$ \\
\hline Number of good news disclosures & 137 & 27.4 & $20.03 \%$ & 67 & 13.4 & $21.61 \%$ \\
\hline Number of $b a d$ news disclosures & 39 & 7.8 & $5.70 \%$ & 59 & 11.8 & $19.03 \%$ \\
\hline Number of neutral news disclosures & 508 & 101.6 & $74.27 \%$ & 184 & 36.8 & $59.35 \%$ \\
\hline
\end{tabular}




\begin{tabular}{|c|c|c|c|c|c|}
\hline & 684 & & $100.00 \%$ & 310 & $100.00 \%$ \\
\hline Number of risk categories disclosed & & 4.8 & & 3.2 & \\
\hline Number of specific RD section in IR & & 1.1 & & 0.8 & \\
\hline
\end{tabular}

Table 2 also confirms the backward-looking orientation of both the documents in providing RD disclosure, showing a prevalence of past related risk disclosures $(58.77 \%$ and $55.81 \%)$ rather than the predominance of neutral news disclosures (74.27\% and 59.35\%). As stated above, these results reveal the inability of some managers in formulating forward-risk models. Furthermore, it highlights the desire to protect some unverified information that could encourage competitors and lead to greater costs for the company linked to competitive disadvantages (Lajili \& Zeghal, 2005; Linsley \& Shrives, 2006; Dobler, 2008; Abraham \& Shrives, 2014).

\section{Conclusions}

Nowadays there is a high demand for risk related information by stakeholders in assessing future performance of organisations as well as for decision making. Under the umbrella of the stakeholders theory, the present paper investigates the extent of information on risks and opportunities provided by Italian companies in their IR. Moreover, whether possible, information disclosed in the IR has been compared with risk information provided in the management commentary to assess the extent to which Italian companies are improving their attitude to provide more detailed and comprehensive information whilst adopting IR.

Collected results demonstrate, at least for Italian companies, a more extended risk disclosure provided in the IR in comparison with the MC. In particular, companies seem to be more inclined to disclose operations risk, financial risk and integrity risk, while the type of risk less discussed is related to empowerment. Organisations demonstrate a high attention to environmental, health and safety as well as customer satisfaction issues, confirming a trend already underlined in studies devoted to sustainability disclosure in the same context.

A tendency to adopt a neutral tone has been identified, with a reduced disclosure of both good and bad news, possibly to avoid legal costs or loss of reputation, as previously highlighted by scholars.

Interestingly, while adopting IR, the organisation tends to distribute risk-related information throughout the whole document, rather than in a particular section of the document. This results in being considered as consistent with an approach more devoted to demonstrating an integrated thinking adopted while managing the company.

A further results emerging from the analysis is the more detailed risk disclosure provided in the IR in comparison with Management Commentary. This evidence seems to corroborate the opportunity for an integrated approach to corporate disclosure, better suited for offering paramount information to any type of stakeholder.

However, a tendency to provide merely qualitative information persists. Similarly, a backwards approach is widely preferred to a forward-looking approach, limiting the opportunity for stakeholders to evaluate possible future impacts of risks faced by the organisation. Furthermore, this approach hides the possibility to assess the ability of managers in adopting a suitable and appropriate policy to tackle risks.

Considering IR as a tool located in the area of voluntary disclosure, this research contributes to different strands of research. Firstly, results collected through content analysis contribute to the literature on voluntary disclosure and more precisely to the branch interested in risk disclosure. Moreover, the paper offers fresh knowledge on a new tool for corporate reporting, the IR.

The research could be beneficial from a threefold perspective. For standard setters, to bring them up to date with enhanced disclosure of risk and opportunities which IR offers in comparison to the more traditional forms of disclosure, setting the context to discuss to what extent standards supporting the preparation of this new tool are necessary. For legislators, in order to consider whether and to whom - in the light of Directive 2013/34/EU explicit encouragement towards the adoption of IR should be given. For scholars, to increase their capacity to analyse trends and their knowledge of the role of integrated thinking in setting up business strategies that combine sustainability, good governance and risk management.

However, some limitations have also to be considered. The empirical analysis is related to one year, while a longitudinal study would offer further room for a better understanding of the evolution of risk disclosure through IR. The research considers one country, Italy, whilst comparative studies in the field would be beneficial for regulators - particularly in Europe, where non-financial information is required by prominent organisations - to discuss the opportunity to provide guidelines or detailed regulations on integrated reporting. Thus, future development of the research may replicate the analysis in a comparative approach, as well as investigate possible 
determinants of risk disclosure in the IR.

\section{References}

Abeysekera, I. (2013). A Template for Integrated Reporting. Journal of Intellectual Capital, 14(2), 227-245. http://dx.doi.org/10.1108/14691931311323869

Abraham, S., \& Cox, P. (2007). Analysing the determinants of narrative risk information in UK FTSE100 annual reports. The British Accounting Review, 39(3), 227-248. https://doi.org/10.1016/j.bar.2007.06.002

Abraham, S., \& Shrives, P. J. (2014). Improving the relevance of risk factor disclosure in corporate annual reports. The British accounting review, 46(1), 91-107. https://doi.org/10.1016/j.bar.2013.10.002

Adams, C. A., \& Kuasirikun, N. (2000). A comparative analysis of corporate reporting on ethical issues by UK and German chemical and pharmaceutical companies. European Accounting Review, 9(1), 53-79. http://dx.doi.org/10.1080/096381800407941

Adams, S., \& Simnett, R. (2011). Integrated Reporting: An opportunity for Australia's not for profit sector. Australian Accounting Review, 21(3), 292-301. http://dx.doi.org/10.1111/j.1835-2561.2011.00143.x

AICPA (1994). Disclosure of certain significant risks and uncertainties. Statement of Position 94-6. New York, NY: AICPA.

Alexander, D., \& Servalli, S. (2011). Economia Aziendale and financial valuations in Italy: Some contradictions and insights. Accounting History, 16(3), 291-312. https://doi.org/10.1177/1032373211407052

Allini, A., Manes-Rossi, F. \& Macchioni, R. (2014). Do corporate governance characteristics affect non-financial risk disclosure in government-owned companies? The Italian experience. Financial Reporting, 1, 5-31. https://doi.org/10.3280/FR2014-001001

Allini, A., Manes Rossi, F. \& Hussainey, K. (2016). The board's role in risk disclosure: an exploratory study of Italian listed state-owned enterprises. Public Money \& Management, 36(2), 113-120. http://dx.doi.org/10.1080/09540962.2016.1118935

Amran, A., Manaf Rosli Bin, A., \& Che Haat Mohd Hassan, B. (2008). Risk reporting: An exploratory study on risk management disclosure in Malaysian annual reports. Managerial Auditing Journal, 24(1), 39-57. http://dx.doi.org/10.1108/02686900910919893

Barth, M. E., \& Cahan, Steven, F., Chen, L., \& Venter, E. R. (2016). The Economic Consequences Associated with Integrated Report Quality: Capital Market and Real Effects. Retrieved from https://ssrn.com/abstract=26994099

Becht, M. (1997). Strong blockholders, weak owners and the need for European mandatory disclosure. The separation of ownership and control: A survey of 7 European countries. Preliminary Report to the European Commission, Brussels.

Beretta, S., \& Bozzolan, S. (2004). A framework for the analysis of risk communication. The International Journal of Accounting, 39(3), 265-276. https://doi.org/10.1016/j.intacc.2004.06.006

Busco, C., Frigo, M. L., Quattrone, P., \& Riccaboni, A. (2013). Redefining corporate accountability through integrated reporting: what happens when values and value creation meet? Strategic Finance, 95(2), 33-42.

Cohen, J., Krishnamoorthy, G., \& Wright, A. (2017). Enterprise risk management and the financial reporting process: The experiences of audit committee members, CFOs, and external auditors. Contemporary Accounting Research. http://dx.doi.org/10.2139/ssrn.2444397

COSO. (2004). Enterprise risk management-integrated framework. The Committee of Sponsoring Organizations of the Treadway Commission, New York.

De Villiers, C., Rinaldi, L., \& Unerman, J. (2014). Integrated Reporting: Insights, gaps and an agenda for future research. Accounting, Auditing \& Accountability Journal, 27(7), 1042-1067. http://dx.doi.org/10.1108/AAAJ-06-2014-1736

Deegan, C. (2000). Financial Accounting Theory. McGraw-Hill Book Company, Sydney.

Deumes, R., \& Knechel, W. R. (2008). Economic incentives for voluntary reporting on internal risk management and control systems. Auditing: A Journal of Practice \& Theory, 27(1), 35-66. http://dx.doi.org/10.2308/aud.2008.27.1.35

Dobler, M. (2008). Incentives for risk reporting-A discretionary disclosure and cheap talk approach. The 
International Journal of Accounting, 43(2), 184-206. https://doi.org/10.1016/j.intacc.2008.04.005

Eccles, R., \& Serafeim, G. (2014). Corporate and Integrated Reporting: A Functional Perspective. In Lawler E., Mohrman S., \& O'Toole J. (Eds.), Stewardship of the Future. Retrieved from https://ssrn.com/abstract=2388716 or http://dx.doi.org/10.2139/ssrn.2388716

Eccles, R., \& Krzus, M. (2010). One report: Integrated reporting for a sustainable strategy. Hoboken, NJ: Wiley $\&$ Sons.

Elkington, J. (2009). The holy grail of integrated reporting. Sustainability. Retrieved from http://sustainability.com/our-work/insights/the-holy-grail-of-integrated-reporting/

Enslin, Z., Bruwer, W., \& Viljoen, C. (2015). Enhancing risk-related disclosure in South Africa: a study on guidelines and current practices. Journal of Economic and Financial Sciences, 8(1), 261-280.

Eurosif, ACCA. (2013). What do investors expect from non-financial reporting? Retrieved from: http://www. accaglobal.com/content/dam/acca/global/PDFtechnical/sustainability-reporting/tech-tp-wdir.pdf

Frías-Aceituno, J., Rodríguez-Ariza, L., \& Garcia-Sánchez, I. M. (2015). Explanatory factors of integrated sustainability and financial reporting. Business Strategy and the Environment, 23, 56-72. http://dx.doi.org/10.1002/bse.1765

García-Sánchez, I. M., Rodríguez-Ariza, L., \& Frías-Aceituno, J. V. (2013). The cultural system and integrated reporting. International Business Review, 22, 828-838. https://doi.org/10.1016/j.ibusrev.2013.01.007

German Accounting Standards Board. (2001). Risk reporting (GAS 5). GASB, Berlin

Gray, R. H., Owen, D. L., \& Adams, C. A. (1996). Accounting and Accountability: Changes and Challenges in Corporate Social and Environmental Reporting. Prentice-Hall, Hemel Hempstead.

Guthrie, J., Petty, R., \& Ricceri, F. (2006). The voluntary reporting of intellectual capital: Comparing evidence from Hong Kong and Australia. Journal of Intellectual Capital, 7(2), 254-271. http://dx.doi.org/10.1108/14691930610661890

Haller, A., \& Van Staden, C. (2014). The value added statement-an appropriate instrument for Integrated Reporting. Accounting, Auditing \& Accountability Journal, 27(7), 1190-1216. http://dx.doi.org/10.1108/AAAJ-04-2013-1307

Halbouni, S. S., \& Yasin, A. (2016). Risk Disclosure: Empirical Investigation of UAE Companies' Compliance with International Accounting Standards. International Journal of Business and Management, 11(8), 134.

IASB. (2010). Management commentary, practice statement. London: International Accounting Standards Board. Retrieved http://www.ifrs.org/Current-Projects/IASB-Projects/Management-Commentary/IFRS-Practice-Statement/Doc uments/Managementcommentarypracticestatement8December.pdf.

ICAEW. (2002). No surprises: The case for better risk reporting. London; The Institute of Chartered Accountants in England and Wales. Balance Sheet, 10(4), 18-21.

ICAEW. (2011). Reporting business risks: Meeting expectations. London: Institute of Chartered Accountants of England and Wales. Retrieved from: https://www.icaew.com/ /media/corporate/files/technical/financial\%20reporting/information\%20for\%20bette r\%20markets/ifbm/rbr\%20final.ashx

IIRC. (2013). International $<I R>\quad$ Framework. Retrieved from $\mathrm{http}$ //integratedreporting.org/resource/international-ir-framework

International Organization for Standardization (ISO). (2009). International Standard ISO 31000: Risk Management - Principles and Guidelines. Switzerland: ISO.

Jaggi, B., \&Low, P. Y. (2000). Impact of culture, market forces, and legal system on financial disclosures. The International Journal of Accounting, 35(4), 495-519. https://doi.org/10.1016/S0020-7063(00)00076-5

Jaggi, B., Allini, A., Rossi, F. M., \& Caldarelli, A. (2016). Impact of Accounting Traditions, Ownership and Governance Structures on Financial Reporting by Italian Firms. Review of Pacific Basin Financial Markets and Policies, 19(1), 1650001. http://dx.doi.org/10.1142/S0219091516500016

Jensen, M. C., \& Meckling, W. H. (1976). Theory of the firm: management behaviour, agency costs and ownership structure. Journal of Financial Economics, 3(3), 305-360. https://doi.org/10.1016/0304-405X(76)90026-X 
Kim, S., Maas, K., \& Perego, P. (2017). The Effect of Publication, Format and Content of Integrated Reports on Analysts' Earnings Forecasts. Forthcoming, In Boubaker, S., Cummings, D., \& Nguyen, D. (Eds), The Handbook of Finance and Sustainability. Edward Elgar, 2017. Retrieved from https://ssrn.com/abstract $=2902549$

Kolk, A. (2005). Environmental reporting by multinationals from the triad: Convergence or divergence? Management International Review, 45(1), 145-166.

Krzus, M. P. (2011). Integrated reporting: if not now, when? IRZ(June), 271-276.

Lajili, K. and Zeghal, D. (2005). A Content Analysis of Risk Management Disclosures in Canadian Annual Reports. Canadian Journal of Administrative Sciences, 22(2), 125-142. http://dx.doi.org/10.1111/j.1936-4490.2005.tb00714.x

Linsley P. M., \& Shrives, P. J. (2006). Risk reporting: A Study of risk disclosures in the annual reports of UK companies. British Accounting Review, 38(4), 387-404. https://doi.org/10.1016/j.bar.2006.05.002

Linsley, P. M., Shrives, P. J., \& Crumpton, M. (2006). Risk disclosure: An exploratory study of UK and Canadian banks. Journal of Banking Regulation, 7(3-4), 268-282. 10.1057/palgrave.jbr.2350032

Linsley, P. M., \& Lawrence, M. J. (2007). Risk reporting by the largest UK companies: readability and lack of obfuscation. Accounting, Auditing \& Accountability Journal, 20(4), 620-627. http://dx.doi.org/10.1108/09513570710762601

Lubatkin, M., Lane, P. J., Collin, T., \& Very, P. (2007). An embeddedness framing of governance and opportunism: towards a cross-nationally accommodating theory of agency. Journal of Organizational Behaviour, 28, 43-58. http://dx.doi.org/10.1002/job.402

Melis, A., Carta, S., \& Gaia, S. (2012). Executive director remuneration in blockholder-dominated firms: How do Italian firms use stock options? Journal of Management and Governance, 16(3), 511-541. http://dx.doi.org/10.1007/s10997-010-9163-0

Milne, M., \& Adler, R. (1999). Exploring the reliability of social and environmental disclosures content analysis. Accounting, Auditing and Accountability Journal, 12(2), 237-256. http://dx.doi.org/10.1108/09513579910270138

Moolman, J., Oberholzer, M., \& Steyn, M. (2016). The effect of integrated reporting on integrated thinking between risk, opportunity and strategy and the disclosure of risks and opportunities. Southern African Business Review, 20(1), 600-627.

Oliveira, J., Lima Rodrigues, L., \& Craig, R. (2011). Risk-related disclosures by non-finance companies: Portuguese practices and disclosure characteristics. Managerial Auditing Journal, 26(9), 817-839. http://dx.doi.org/10.1108/02686901111171466

Perego, P., Kennedy, S., \& Whiteman, G. (2016). A lot of icing but little cake? Taking integrated reporting forward. Journal of Cleaner Production, 136, 53-64. https://doi.org/10.1016/j.jclepro.2016.01.106

Power, M. (2004). The risk management of everything: Rethinking the politics of uncertainty. Demos.

PwC (2013). Measuring and managing total impact: A new language for business decisions. Retrieved from https://www.pwc.com/gx/en/sustainability/publications/total-impact-measurement-management/assets/pwc-ti mm-report.pdf.

Quarchioni, S., \& Trovarelli, F. (2013). Approaching Risk Management from a New Integrated Perspective. In Busco et al. Integrated Reporting (pp. 159-170). Springer International Publishing. http://dx.doi.org/10.1007/978-3-319-02168-3_10

Raemaekers, K., Maroun, W., \& Padia, N. (2016). Risk disclosures by South African listed companies post-King III. South African Journal of Accounting Research, 30(1), 41-60. http://dx.doi.org/10.1080/10291954.2015.1021583

Smith, M., \& Taffler, R. J. (2000). The chairman's statement-A content analysis of discretionary narrative disclosures. Accounting, Auditing \& Accountability Journal, 13(5), 624-647. http://dx.doi.org/10.1108/09513570010353738

Solomon, J., Solomon, A. and Norton, S. (2000). A conceptual framework for corporate risk disclosure emerging from the agenda for corporate governance reform. British Accounting Review, 32, 447-478. https://doi.org/10.1006/bare.2000.0145 
Solomon, J. F., Solomon, A., Norton, S. D., \& Joseph, N. L. (2011). Private climate change reporting: An emerging discourse of risk and opportunity? Accounting, Auditing \& Accountability Journal, 24(8), 1119-1148. http://dx.doi.org/10.1108/09513571111184788

Spira L. F., \& Page, M. (2003). Risk management: the reinvention of internal control and the changing role of internal audit. Accounting, Auditing \& Accountability Journal 16(4), 640-661. http://dx.doi.org/10.1108/09513570310492335

Van der Stede, W. (2009). Enterprise governance. Risk and Performance Management through the Business Cycle. CMA Management, May.

Watts, R. L., \& Zimmerman, J. L. (1986). Positive Accounting Theory, Prentice-Hall, Englewood Cliffs, NJ.

Weber, R. P. (1990). Basic content analysis (No. 49). Sage.

Woods, M., \& Reber, B. (2003). A comparison of UK and German reporting practice in respect of risk disclosures post GAS 5. In 26th Annual Congress of the European Accounting Association. Sevilla, España.

\section{Copyrights}

Copyright for this article is retained by the author(s), with first publication rights granted to the journal.

This is an open-access article distributed under the terms and conditions of the Creative Commons Attribution license (http://creativecommons.org/licenses/by/4.0/). 